TILTAI, 2019, 1, 86-107 ISSN 1392-3137 (Print), ISSN 2351-6569 (Online)

\title{
VERTYBIŲ KOMUNIKACIJOS YPATYBE்S LIETUVOS POLITINIŲ PARLAMENTINIŲ PARTIJŲ PROGRAMOSE (2016 METŲ RINKIMŲ ATVEJIS)
}

\author{
Daiva Sirtautienè, Lilija Petraitiené \\ Klaipédos universitetas, Klaipédos valstybinè kolegija
}

\begin{abstract}
Anotacija
Straipsnyje pateikiami 2016 m. rinkimus ị LR Seimą laimëjusių partijų (LVŽS, LSDP, TS-LKD, LRLS, TT, LLRA-KŠS) vertybių komunikacijos rinkiminèse programose analizès rezultatai. Pasitelkus tris programų tyrimo kriterijus - teminių dalių apimties, semantinių segmentų ir ideologinių vertybių - spręsti klausimai: kokia yra 2016 m. rinkimus ị Lietuvos Seimą laimejjusių partijų vertybinių nuostatų jungtis ir skirtumai; ar tradicinès partijos yra išlaikiusios ideologinę tapatybę; kokios koalicijos Seime po rinkimų buvo galimos vertybiniu pagrindu? Tyrimo duomenys atskleide, kad visuomenei aktualių vertybių komunikacija visose tirtose programose yra labai panaši, o ideologinių vertybių komunikacijos jungtys klasteriniu metodu atrastos pirmiausia tarp tradicinių partijų. Antraji klasterị sudaro nebe tiek tarpusavyje susijusios kitų partijų programos. Beveik identiška situacija nustatyta tiriant šį aspektą programų struktūrinių dalių pagrindu. Taigi nustatyti du paskiri struktūriniai vienetai su didesniais (pirmuoju atveju) ir mažesniais (antruoju) tarpusavio ryšiais.

PAGRINDINIAI ŽODŽIAI: vertybès, komunikacija, 2016 metų Seimo rinkimai, Lietuvos partijos, programos.
\end{abstract}

\begin{abstract}
The article discusses the results of value-based communication analysis in the electoral programs of winning parties in Republic of Lithuania Seimas'2016 year election (LVŽS, LSDP, TS-LKD, LRLS, TT, LLRA-KŠS). With the application of three criteria of programs' analysis - the volume of thematic parts, semantic segments, and ideological values - these questions were addressed: the connection and differences between winner parties' attitudes towards values; whether traditional parties have preserved ideological identity; what coalitions after the election in the Seimas were possible based on values. The research data revealed that communication of values relevant to society in all analyzed programs is very similar, and, through cluster analysis, the connections between ideological values' communication were established foremost between traditional parties (first cluster). The second cluster consists of less related programs of other parties. Almost identical results were established when analysing this aspect based on programs' structural parts. Thus two separate structural elements with stronger (first case) and weaker (second case) interconnections were determined.
\end{abstract}

KEY WORDS: values, communication, 2016 Seimas election, parties of Lithuanian, programs.

DOI: http://dx.doi.org/10.15181/tbb.v82i1.1964

\section{Ivadas}

Amžina tema visose žmogiškosios būties srityse - vertybės. Stebint kalbejjimą apie jas mokslo pasaulyje, išryškèja bendros jų aptarties tendencijos: 1) vertybés, kaip asmens individualus turtas, kuriuo remiantis konstruojamas gyvenimas; 
2) vertybès, kaip visuomenès normos, padedančios joje tinkamai funkcionuoti; 3) vertybès, kaip iš vidaus ar išorès deleguojamas turinys, siekiant koreguoti (ar keisti) esamąsias. Nedetalizuojant įžvalgų apie vertybių, kaip fenomeno, jų nuvertejjimo, kaip reiškinio, ar stabilaus ir puoselètino kultūrinio paveldo, sampratos (Baudrillard, 2002; Popper, 1982; Habermas, 1983; Nietzsache, 1991; Scheler, 2012; Pruskus, 2005; Jovaiša, 2009; Norkus, 1995; Žiliukaitè, 2006), straipsnyje pristatomame tyrime dèmesys sutelktas ị politinių partijų visuomenei komunikuojamas vertybes priešrinkiminių programų tekstuose.

Programa, kaip partijos vertybių komunikacijos šaltinis, nėra tiek ,aktyvuota“ visuomenèje kaip, pvz., žiniasklaida, kurios poveikio, taip pat ir politinio, mechanizmų spektrą detaliai analizavęs L. Bielinis, be kita ko, teigia, „,kad politika tampa masinès kultūros elementu“ (2005, p. 123), o ,pasinaudoti žiniasklaida, vadinasi, pasinaudoti jèga“" (Ten pat, p. 60-61). Tačiau pažymètina, kad partijos programa yra apmąstytas dokumentas, kuriame fiksuojami vertybiniai turiniai, apibrèžiantys esmines valstybès valdymo nuostatas. Tad partijų programos, kaip stabilus priešrinkiminis turinys, tyrimui yra parankus, nors žvelgiant ị vertybių tyrimus politikos lauke, matomos ịvairios metodologinès prieigos, pvz., M. Jastramskis, teigdamas, kad ,vienu patikimiausių metodų laikomas pačių partijų narių ir jų lyderių politinių [...] nuostatų tyrimas“ (2013, p. 12), nurodo: „Partijų vertybines orientacijas galima tirti ịvairiais būdais: remiantis ekspertų nuomone, partijų programų ir politikų pasisakymų analize, taip pat gyventojų apklausomis, vertinant, kokie rinkejjai balsuoja už konkrečias partijas ir kaip suvokia šiu partijų idejjinę kryptį“ (Ten pat).

Kaip galima pastebèti, bet kurios metodologinès prieigos atveju susiduriama su daugiau (pvz., ekspertų nuomonè, apklausos) ar mažiau (pvz., programos) matomu žmogiškuoju veiksniu, kuris gana netolygiai atsiskleidžia ilgesnio laikotarpio vertybinių nuostatų tyrimų rezultatuose. Pvz., teigta: „Vis dèlto nuo $2000 \mathrm{~m}$. Seimo rinkimų Lietuvos politine erdvė èmé irti: nyksta kairès-dešinès skirtis [...], o politiniame diskurse įsitvirtina ,tradicinių - populistinių“ partijų perskyra ir panašūs ivvardijimai“ (Ramonaite, 2007, p. 166-167). Vèliau pateikiami kitokie rezultatai: „Atlikta partijų elito nuostatų analizė rodo, kad Lietuvoje nèra vienos dominuojančios rinkiminès strategijos: vienos partijos siekia formuoti savo ideologinę tapatybę, užimti tam tikrą vertybinę poziciją, o kitos - įtikimo visiems strategiją. 2000-ųjų ir 2004-ųjų Seimo rinkimai leido manyti, kad pastaroji strategija pasiteisina labiau, tačiau 2008 m. rinkimai buvo palankesni ideologiškai nuoseklioms partijoms nei ankstesni““ (Ramonaitè, 2009, p. 52).

Vèliau, atlikus kandidatų ị 2012 m. Seimą apklausą, konstatuota, kad „Lietuvoje yra trys ideologiškai „tvarkingos“ partijos - socialdemokratų, liberalų ir krikščionių demokratų - kurių nuostatos daugiau ar mažiau gerai atitinka vakarietišką šių ideologijų supratimą“ (Ramonaitè, Jastramskis, 2014, p. 138). Be to, kalbama 


\section{Daiva Sirtautienė, Lilija Petraitienè}

apie tris vertybines dimensijas, struktūruojančias Lietuvos partinę sistemą: ekonominę (reguliuojama - laisva rinka), moralinę (konservatyvumas - liberalumas) ir santykių su gretimomis Rytų šalimis bei sovietinès praeities teigiamas ar neigiamas vertinimas (Ten pat, p. 134-135).

Pasak M. Jastramskio, ,nors politikų vertybės paprastai suvokiamos kaip nulemtos socialinio konteksto, kuriame jie veikia, tiriant partines sistemas ir rinkèjų elgseną naujose demokratijose, remiamasi ir kitokiu požiūriu - kad partijos pačios gali suformuoti bei skleisti tam tikras vertybes, taip prisidèdamos prie idejjinių takoskyrų visuomenèje kūrimo. Taigi politinių partijų deklaruojamos idèjos gali daryti įtaką ir šalies gyventojų vertybèms“ (2013, p. 2). Tačiau, ištyrus Lietuvos integracijos į Šiaurès Baltijos šalių regioną bendrų vertybių pagrindu prielaidas, pastebima, kad ,pačių partijų ir politikų vertybinės nuostatos tarpusavyje skiriasi, o praktiniuose sprendimuose deklaruojamų nuostatų laikomasi ne visada“ (2013, p. 3), tad esant šioms aplinkybėms daryti poveikị šalies gyventojų vertybėms turbūt nebūtų paprasta. Juolab kad ir pačių rinkèjų vertybinès nuostatos gana prieštaringos: „Abstraktūs ideologiniai ịvardijimai - kairè - dešinè, liberalizmas ir pan. patys savaime mažai ką reiškia. Besivardinantieji liberalais gali lygiai taip pat būti netolerantiški mažumoms arba pritarti mokesčių perskirstymui kaip krikščionys demokratai ar socialdemokratai“" (Ramonaitè, Jastramskis, 2014, p. 143-144).

Galima manyti, kad abiem atvejais (tiek politikų, tiek rinkejjų) pirmiausia susiduriama su konkretiems žmonèms, net ir konkrečiai partijai priklausantiems, asmeniškai reikšmingomis vertybèmis, kurios nebūtinai susidèlioja ị nuoseklią, ideologiškai apibrèžtą struktūrą.

Pastaruoju metu kalbama apie nestabilumą ir kaitą, kuriuos dar kartą atskleidè netikèti 2016 m. rinkimų į Lietuvos Seimą rezultatai. M. Jastramskis, remdamasis A. Ramonaitès įžvalgomis, metaforiškai tai palygino su žemės drebėjimu: „Rinkèjai ne pirmą kartą praktiškai ịrodè, kad jų preferencijos yra nestabilios: visgi daugiau žinome apie mažai elektorato daliai būdingą tapatybę, o ne tai, kokia logika veikia balsams pereinant tarp skirtingų partijų (ar tarp balsavimo ir nebalsavimo)““(2017, p. 5). „Panašu, kad po 2016 rinkimų diskusijas dẻl Lietuvos partinès sistemos logikos reikia vertinti iš naujo, dar kartą kritiškai klausiant: ar apskritai Lietuvos partijų visuma yra verta sistemos vardo?“" (Ten pat).

Galbūt racionali buvo dar 1995 metais J. Novagrockienès pateikta ịžvalga, kad „partijos sėkmė rinkimuose yra nulemta piliečių lūkesčių [...], partijos ar partijų pagrindu suformuotos vyriausybės sugebèjimo reaguoti i piliečių lūkesčius, o šis sugebèjimas betarpiškai nulemia jų sėkmę ar nesėkmę rinkimuose“ (Novagreckienè, 1995, p. 63). Žinia, lietuviai yra kantrūs žmonès: jie kantriai laukia naujos lūkesčius pateisinsiančios jẻgos, dar nė karto neapvylusios, bet, jei tokia neatsiran- 
da, renkasi iš to, kas yra (paprastai pamaininiu būdu), sudarydami partijų sistemos stabilizavimosi iliuziją.

Žvelgiant ị glaustai aptartą Lietuvos politinès erdvès dinamiką, matyti jos permanentinių tyrimų reikmè ir aktualumas, kadangi susiduriama su šios erdvès, kaip plataus tyrimo objekto, daugiakomponentiškumo (rinkejjai, politikai, partijos, elgsena, valdymo procesas, rinkimai, rezultatai, komunikacija ir t. t.), ryšių bei sąveikų įvairove, nevienodai pasireiškiančia skirtingų laikotarpių ir socialinių kontekstų plotmejje. Artejjant 2020 metų rinkimams ị Seimą ir žinant jau ịvykusius ar tebevykstančius pokyčius valdančiosios koalicijos struktūroje (sietinus ir su LSDP skilimu), tyrimo rezultatai galètų būti aktualūs tiek partijų savianalizei, nusistatant realius dominantinius prioritetus programose, tiek ir rinkejams, siekiant ịvertinti partijos galimybę atstovauti jų interesams LR Seime.

Šiame straipsnyje pristatomo tyrimo objektas - politinių partijų, laimejjusių rinkimus ị Lietuvos Respublikos Seimą 2016 metais, vertybių komunikacijos ypatybès rinkimų programose: Tẻvynès sajungos-Lietuvos krikščionių demokratu (TS-LKD), Lietuvos Respublikos liberalų sajūdžio (LRLS), Lietuvos socialdemokratu partijos (LSDP), Lietuvos valstiečių ir žaliujų sajungos (LVŽS), Lietuvos lenkų rinkimų akcijos-Krikščioniškų šeimų sajungos (LLRA-KŠS), Tvarka ir teisingumas (TT).

Atsižvelgiant ị objektą, formuluotas apibendrintas tyrimo tikslas: išanalizuoti programose deklaruojamų vertybių ypatybes.

Tyrimu siekta atsakyti ị šiuos klausimus:

1. Kokia yra vertybinių nuostatu jungtis ir skirtumai $2016 \mathrm{~m}$. rinkimus ị Lietuvos Seimą laimèjusių partijų programose?

2. Ar tradicinès partijos yra išlaikiusios ideologinę tapatybę?

3. Kokios galimos vertybiniu pagrindu pagrịstos koalicijos Seime po rinkimų?

Uždaviniai :

1. Išnagrinejus programas, sudaryti apibendrintą, visoms joms būdingą turinio struktūrą.

2. İvertinti partijų ideologinès tapatybės raišką jų programose.

3. Atskleisti tarpprogramines deklaruojamų vertybių jungtis ir skirtumus.

Tyrimo metodologija ir eiga

Tyrimo metodai: kiekybinè turinio, struktūrinè analizè, lyginimas, konkordansų metodas, procentinė ir koreliacinè analizès, hierarchinių klasterių metodas. Metodai pasirinkti atsižvelgiant $\mathfrak{i}$ imties specifiką: programų tekstai pateikti elektronine forma, tad paranku buvo ne tik nustatyti kokybinius tyrimo objekto parametrus, bet ir skaičiuoti kiekybinius vienetus. Reikètų pastebèti, kad statisti- 


\section{Daiva Sirtautienė, Lilija Petraitienè}

nių politikos lauko tyrimų Lietuvos mokslininkų darbuose nėra daug, čia labiausiai norėtųsi išskirti M. Jastramskio darbus (jau cituotus ịvade). İvairių agentūrų atliekamose visuomenès apklausose apie politikų reitingus ar rinkimų prognozes paprastai tenkinamasi procentinès analizès rezultatais, kurie negali parodyti ryšių ir jų hierarchijos. Todèl tyrime taikytas kompleksas metodų, ịgalinančių ịvairiapusiškiau pažvelgti i tyrimo objektą: kiekybinė turinio analizè, leidžianti objektyviai ir sistemiškai išnagrinèti programų teksto ypatybes; konkordansų metodas (angl. key-word-in-context - KWIC), igalinantis išskirti koduojamus stebèjimo vienetus ir nustatyti jų kiekị programų tekstuose; koreliacinė analizė, atskleidžianti ryšių tarp tiriamųjų vienetų stiprumą; hierarchinių klasterių metodas, kurio rezultatai nusako objektų (klasterių) tarpusavio hierarchiją (Čekanavičius, Murauskas, 2004, p. 202-203), šio tyrimo atveju - partijų programų panašumo struktūrą.

Siekiant kuo tikslesnių tyrimo rezultatų, analizei taikyti trys kriterijai: 1) programų turinio apimtis; 2) programų turinio semantiniai segmentai; 3) ideologinès vertybès programose. Tikètasi, kad trimis skirtingais kriterijais gautų duomenų palyginimas parodys panašius rezultatus, o nuo to, kiek jie panašūs, priklausys tyrimo validumas, konkrečiau, kiek (ir ar) trečiasis - ideologinių vertybių (paremtų pirmiausia istorine partijų raida) - kriterijus sietinas su logiškai tarpusavyje galimais susieti pirmaisiais dviem (paremtais pirmiausia dabarties socialinio konteksto aktualijomis).

Pirmajame etape, išanalizavus programų tematiką ir susisteminus gautus duomenis, sudaryta apibendrinta 9 dalių turinio struktūra, būdinga visoms programoms, bei atliktas jų tarpusavio palyginimas pagal santykinę dalių apimtį.

Antrajame etape, remiantis pirmojo etapo duomenimis, kiekvienoje struktūrinèje programų dalyje išskirti reikšminiai žodžiai, būdingesni konkrečios dalies turiniui ar atskleidžiantys šių dienų visuomenès aktualijas; iš išskirtų reikšmių sudaryti semantiniai segmentai ir apskaičiuoti jų vartojimo dažniai kiekvienoje programoje.

Trečiajame etape, remiantis istoriniu ir (ar) esamu partijų vertybiniu kryptingumu, išskirtos 19-ai partijų būdingos ideologinès vertybès, deklaruojamos programose, ir apskaičiuoti vartojimo dažniai kiekvienoje iš jų.

Ketvirtajame etape, remiantis visų trijų kriterijų duomenimis, tirti ryšiai tarp partijų programų, nustatyta ryšių hierarchija.

\section{Partijų programų struktūrinès analizès rezultatai}

1 lentelèje pateikti pirminiai tyrimo imties duomenys, rodantys tekstinę programų apimtí (žodžių skaičius). 
VERTYBIŲ KOMUNIKACIJOS YPATYBĖS LIETUVOS POLITINIŲ PARLAMENTINIŲ...

1 lentele. Tyrimo imtis

\begin{tabular}{|l|l|l|l|l|l|l|l|}
\hline \multirow{2}{*}{$\begin{array}{l}\text { Žodžių } \\
\text { skaičius }\end{array}$} & \multicolumn{4}{|l|}{ Partijų programos } & \multirow{2}{*}{ Iš viso } \\
\cline { 2 - 8 } & LVŽS & LSDP & TT & TS-LKD & LRLS & LLRA-KŠS & \\
\hline $\begin{array}{l}\text { Absoliutieji } \\
\text { dažniai }\end{array}$ & 43898 & 8918 & 6248 & 85111 & 33526 & 5330 & $\mathbf{1 7 7 7 0 1}$ \\
\hline $\begin{array}{l}\text { Procentiniai } \\
\text { dažniai }\end{array}$ & $24 \%$ & $4,9 \%$ & $3,4 \%$ & $46,5 \%$ & $18,3 \%$ & $2,9 \%$ & $100 \%$ \\
\hline
\end{tabular}

Žvelgiant ị pirmoje lentelëje pateiktus tekstinès apimties procentinius dažnius, matomas išplètotų ir, lyginant su pastarosiomis, kompaktiškų priešrinkiminių programų spektras. Galima būtų pastebèti, kad dvigubai trumpesnè (24 \%) LVŽS programa, lyginant su labiausiai išplètota $(46,5 \%)$ TS-LKD, nebuvo kliūtis pirmajai partijai didžiaja dauguma laimèti rinkimus ị Seimą 2016 m., kaip ir trumpos TT $(3,4 \%)$ ar LLRA-KŠS $(2,9 \%)$ programos - patekti i jit.

Išanalizavus programose pateiktas temines sritis, išryškejo devynios struktūrinès dalys, būdingos visoms programoms, tad tuo remiantis sudaryta apibendrinta jų struktūra. Išskirtų dalių apimties santykis kiekvienoje iš tirtų programų pateiktas 2 lenteleje. Atkreiptinas demesys, kad santykiniai dažniai taikyti, siekiant nustatyti konkrečios programos teminès dalies santykị su visos programos tekstu.

2 lentelè. Teminių dalių apimtys partijų programų struktūrose (žodžių skaičiaus santykiniai dažniai, procentais)

\begin{tabular}{|c|c|c|c|c|c|c|c|c|}
\hline \multirow[b]{2}{*}{$\begin{array}{l}\text { Eil. } \\
\text { Nr. }\end{array}$} & \multirow{2}{*}{$\begin{array}{l}\text { Struktūrinės } \\
\text { programų dalys }\end{array}$} & \multicolumn{6}{|c|}{ Partijos } & \multirow{2}{*}{$\begin{array}{l}\text { Viduti- } \\
\text { niškai }\end{array}$} \\
\hline & & LVŽS & LSDP & TT & TS-LKD & LRLS & $\begin{array}{l}\text { LLRA- } \\
\text { KŠS }\end{array}$ & \\
\hline 1. & ŪKIO AUGIMAS & 11 & 32 & 24 & 38 & 34 & 12 & 25 \\
\hline 2. & ŠVIETIMAS & 8 & 5 & 42 & 14 & 14 & 12 & 16 \\
\hline 3. & \begin{tabular}{|l} 
ŽMOGAUS, \\
VALSTYBĖS \\
SAUGUMAS
\end{tabular} & 10 & 20 & 2 & 10 & 13 & 16 & 12 \\
\hline 4. & $\begin{array}{l}\text { SVEIKATOS } \\
\text { APSAUGA }\end{array}$ & 19 & 10 & 8 & 5 & 7 & 8 & 9 \\
\hline 5. & $\begin{array}{l}\text { SOCIALINE் } \\
\text { APSAUGA }\end{array}$ & 14 & 6 & 9 & 9 & 6 & 10 & 9 \\
\hline 6. & $\begin{array}{l}\text { VALSTYBE், VIE- } \\
\text { TOS SAVIVALDA }\end{array}$ & 4 & 7 & 5 & 8 & 9 & 18 & 9 \\
\hline 7. & TEISINGUMAS & 13 & 10 & 4 & 6 & 4 & 7 & 7 \\
\hline 8. & KULTŪRA & 6 & 8 & 3 & 5 & 3 & 14 & 7 \\
\hline 9. & $\begin{array}{l}\text { APLINKOS } \\
\text { SAUGOJIMAS }\end{array}$ & 14 & 4 & 3 & 5 & 10 & 3 & 6 \\
\hline
\end{tabular}


2 lentelëje pajuodintu šriftu išskirti teminių dalių dažniai, rodantys labiausiai konkrečioje partijos programoje aktualizuotas sritis, palyginus su tos pačios srities aktualizacija kitose programose. Taip atskleidžiamos ir akcentuojamos tam tikros vertybinès nuostatos, nes kitaip teksto plètoté neatrodytų racionali.

Šiuo kriterijumi lyginant programas tarpusavyje, reikètų pastebèti, kad LVŽS programoje išryškèja net keturios prioritetinès sritys (sveikatos apsauga, socialinė apsauga, teisingumas ir aplinkos saugojimas, kuris, kaip žinoma, yra žaliujų ideologinė vertybė), išskiriančios šią programą iš likusiųjų. Kaip rodo anksčiau atlikto visuomenès vertybinių prioritetų tyrimo rezultatai (Sirtautas, Sirtautienė, 2013, p. 88), sveikata, teisingumas ir saugumas (plačiaja prasme) respondentų priskirti prie svarbiausių vertybių. Tai, kad visos jos aktualizuotos LVŽS programoje, galèjo turèti ịtakos ir rinkimų rezultatams, užsitikrinant Seime daugumą.

Kitų partijų programose (išskyrus LLRA-KŠS) ryškiau atskleista tik kuri nors viena sritis: LSDP - žmogaus ir valstybès saugumas; TT - švietimas (beje, išsilavinęs žmogus visuomenei - didelè vertybè, bent jau turètų būti); TS-LKD - ūkio augimas. LLRA-KŠS programoje išsiskiria du - valstybès, vietos savivaldos bei kultūros komponentai ir tai atrodo logiška, žinant šios partijos tautinio pagrindo specifiką. LRLS programa statistiškai labai artima TS-LKD programai, išskyrus aplinkos saugojimo sritị. İdomu pastebèti, kad TT partija, kurios pavadinime yra žodis teisingumas, jam programoje skiria mažiausia dèmesio, lyginant su kitomis partijomis (kartu su LRLS - po 4 proc.).

Kaip jau rašyta įvade, partijos programa yra apgalvotai parengtas dokumentas, kuriame fiksuojami vertybiniai turiniai, apibrèžiantys esmines valstybès valdymo nuostatas. Taigi, matant teminių sričių programose apimties rezultatus (tik žodžių skaičiaus santykiniais dažniais), galima pastebèti deklaruojamų programinių nuostatų pagrindu skirtingai išplètotą spektrą: sveikas ir saugus žmogus bei jo aplinka, ūkis (ekonomika), valstybè ir savivalda, švietimas, kultūra.

Ryšiams tarp partijų programų pagal teminių dalių apimtį nustatyti taikytas koreliacinès analizès metodas. Rezultatai pateikti 3 lentelèje.

3 lentele . Ryšiai tarp partijų programų: teminių dalių apimties kriterijus

\begin{tabular}{|l|l|l|l|l|l|l|}
\hline Partijos & LVŽS & LSDP & TT & TS-LKD & LRLS & LLRA-KŠS \\
\hline LVŽS & 1 & -.037 & -.139 & -.117 & -.069 & $-.763^{*}$ \\
\hline LSDP & -.037 & 1 & .129 & $.832^{* *}$ & $.814^{* *}$ & .309 \\
\hline TT & -.139 & .129 & 1 & .534 & .516 & .095 \\
\hline TS-LKD & .117 & $.832^{* *}$ & .534 & 1 & $.958^{* *}$ & .218 \\
\hline
\end{tabular}


VERTYBIŲ KOMUNIKACIJOS YPATYBĖS LIETUVOS POLITINIŲ PARLAMENTINIŲ...

\begin{tabular}{|l|l|l|l|l|l|l|}
\hline Partijos & LVŽS & LSDP & TT & TS-LKD & LRLS & LLRA-KŠS \\
\hline LRLS & -.069 & $.814^{* *}$ & .516 & $.958^{* *}$ & 1 & .149 \\
\hline $\begin{array}{l}\text { LLRA- } \\
\text { KŠS }\end{array}$ & $-.763^{*}$ & .309 & .095 & .218 & .149 & 1 \\
\hline
\end{tabular}

*. Koreliacijos koeficiento reikšmingumas atitinka sąlygą $0,01<p<0,05$

**. Koreliacijos koeficiento reikšmingumas atitinka sąlygą $0,01>p$

Pastebėtina, kad užfiksuota tik viena statistiškai reikšminga stipri neigiama koreliacija - tarp LVŽS ir LLRA-KŠS (koreliacijos koeficientas $r=-0.763$ ). Tai rodo, kad šios dvi partijos, remiantis programų dalių apimties kriterijumi, labiausiai skiriasi. Kitos reikšmingos koreliacijos buvo teigiamos: tarp TS-LKD ir LRLS dalių apimties $(r=0,958)$, tarp LSDP ir TS-LKD (koreliacijos koeficientas $r=0,832)$ bei tarp LSDP ir LRLS $(r=0,814)$. Visi šie trys teigiami ryšiai labai stiprūs. Gautas rezultatas ypatingas tuo, kad nematyti skirtumo tarp „kairès“ ir „dešinès“, o pagrindinè jungtis įvardintina tiesiog kaip „tradicinès“, viena nuo kitos programų teminių dalių apimtimi nesiskiriančios partijos.

Kaip galima matyti iš teminių dalių apimties struktūros, ypač išsiskiria LVŽS programa, nes ji labiausiai nesuderinama su kitomis: visi neigiami ryšiai užfiksuoti tik tarp jos ir kitų programų, tiesa, tik vienas iš jų, kaip minèta aukščiau, statistiškai reikšmingas.

\section{Semantinių segmentụ analizès rezultatai}

Darant prielaidą, kad tam tikros srities (iš 9 nustatytujų) vertybinių nuostatu deklaravimas programose nebūtinai tiksliai atskleidžia situaciją, nes yra galimybė jas skleisti per visą programos apimtị, t. y. prioritetai vienaip ar kitaip turètų (ar galètų) matytis visoje konkrečios partijos programoje, tyrimas papildytas taikant semantinių segmentų sklaidos kriterijų.

Kiekvienoje struktūrinėje programų dalyje išskirti pagrindiniai žodžiai (reikšmès), būdingesni konkrečios dalies turiniui ir atskleidžiantys šiu dienų visuomenès aktualijas, kaip vertybinius prioritetus. Taip sudarytas pirminis tyrimo žodynas. Siekta, kad išskirtos reikšmès nebūtų tiesiogiai susijusios su siauresnèmis partijų ideologijomis, bet kuo neutraliau atskleistų programų turinį.

Kiekvienos iš 9 programinių dalių pagrindiniai žodžiai sugrupuoti ị paskirus 9 semantinius segmentus ir apskaičiuoti jų vartojimo dažniai konkrečiose programose. Rezultatai pateikti 4 lentelèje. 
Daiva Sirtautienè, Lilija Petraitienè

4 lentelè. Semantinių segmentų sklaida partijų programose

(santykiniai dažniai, procentais)

\begin{tabular}{|c|c|c|c|c|c|c|c|}
\hline \multirow[b]{2}{*}{ Semantiniai segmentai } & \multicolumn{7}{|c|}{ Partijos } \\
\hline & LVŽS & LSDP & TT & TS-LKD & LRLS- & $\begin{array}{l}\text { LLRA- } \\
\text { Ǩ̆S }\end{array}$ & $\begin{array}{l}\text { Vidu- } \\
\text { tiniš- } \\
\text { kai }\end{array}$ \\
\hline $\begin{array}{l}\text { Švietimas, mokslas, } \\
\text { mokykla, mokytojai, } \\
\text { mokymas, išsilavinimas }\end{array}$ & 12 & 11 & 25 & 17 & 20 & 15 & 17 \\
\hline Socialinè, globa & 7 & 6 & 5 & 5 & 5 & 8 & 6 \\
\hline Sveikata & 6 & 5 & 5 & 2 & 5 & 3 & 4 \\
\hline $\begin{array}{l}\text { Ūkis, ekonomika, vers- } \\
\text { las, inovacijos, iniciaty- } \\
\text { vumas, pajamos, darbo } \\
\text { vietos }\end{array}$ & 17 & 18 & 23 & 22 & 20 & 22 & 20 \\
\hline Kultūra & 7 & 6 & 3 & 6 & 4 & 7 & 6 \\
\hline $\begin{array}{l}\text { Aplinkos apsauga, } \\
\text { gamta }\end{array}$ & 5 & 2 & 2 & 3 & 3 & 3 & 3 \\
\hline Saugumas, saugus & 9 & 13 & 4 & 8 & 10 & 10 & 9 \\
\hline $\begin{array}{l}\text { Teisingumas, teisès, at- } \\
\text { sakomybè, demokratija }\end{array}$ & 15 & 18 & 13 & 14 & 15 & 16 & 15 \\
\hline $\begin{array}{l}\text { Valstybė, savivalda, } \\
\text { visuomené }\end{array}$ & 21 & 21 & 21 & 21 & 17 & 18 & 20 \\
\hline
\end{tabular}

Kaip matyti, segmentų sklaida programose gana panaši. Aptartini kai kurie išsiskiriantys rezultatai, kai tam tikros srities reikšmès, palyginus programas tarpusavyje, daugiausia arba mažiausia išskleistos. Galima pastebėti, kad švietimo segmentas ryškiausias TT programoje (kaip ir tiriant dalių apimtį, žr. 2 lentelę); sveikatos segmento mažiausia atrasta TS-LKD, panašiai ir LLRA-KŠ́ gmentui, mažiau nei kitose programose, tenka LVŽS ir LSDP; mažiausią sklaidą TT ir LRLS programose turi kultūra; aplinkos apsauga ryškiausia LVŽS; didžiausią skirtumą tarp LSDP ir TT galima matyti saugumo segmente; teisingumas labiausiai išryškèjęs LSDP programoje; įdomu, kad valstybès segmentas net keturiose programose atskleistas taip pat (po 21 proc.) ir tik LRLS bei LLRA-KŠS - kiek mažiau. Net po tris partijas tiek pat dėmesio savo programose skiria socialinei 
VERTYBIŲ KOMUNIKACIJOS YPATYBĖS LIETUVOS POLITINIŲ PARLAMENTINIŲ... globai (po 5 proc. TT, TS-LKD ir LRLS), sveikatai (po 5 proc. LSDP, TT, LRLS), aplinkos apsaugai (po 3 proc. TS-LKD, LRLS, LLRA-KŠS). Aplinkos apsaugos, $\bar{u} k i o$, kultūros, saugumo bei teisingumo srityse dar galima pastebėti ir partijų su tokiais pat rezultatais poras (žr., pvz., po 7 proc. LVŽS ir LLRL-KŠS bei po 6 proc. LSDP ir TS-LKD kultūros segmento sklaidoje).

Taigi galima teigti, kad Seimo rinkimus laimèjusios šešios partijos dabarties aktualijas, kaip vertybinius prioritetus, programose deklaruoja panašiai. Tik pastebėtina, kad kartais tokie pat tam tikrų segmentų rezultatai būdingi skirtingų ideologijų partijoms (žr., pvz., LSDP ir LRLS [sveikatos sritis] ar LSDP ir TS-LKD [kultūros sritis]).

Pridurtina, kad kai kurie semantinių segmentų analizès rezultatai pakartojo dalių apimties kriterijaus rezultatus, t. y. tam tikri konkrečių partijų prioritetai skleidžiami ir per visą programą, ne tik plètojami teminèse dalyse: TT - švietimas, LVŽS - sveikata ir apsauga, LSDP - saugumas. Šia prasme teigtinas tam tikras minètų partijų nuoseklumas.

Koreliacinès analizès rezultatai pateikti 5 lentelèje.

5 lentelè. Ryšiai tarp partijų programų: semantinių segmentų kriterijus

\begin{tabular}{|l|l|l|l|l|l|l|}
\hline Partijos & LVŽS & LSDP & TT & TS-LKD & LRLS & LLRA-KŠS \\
\hline LVŽS & 1 & $948^{* *}$ & $839^{* *}$ & $942^{* *}$ & $858^{* *}$ & $925^{* *}$ \\
\hline LSDP & $948^{* *}$ & 1 & $739^{*}$ & $876^{* *}$ & $842^{* *}$ & $906^{* *}$ \\
\hline TT & $839^{* *}$ & $739^{*}$ & 1 & $944^{* *}$ & $960^{* *}$ & $894^{* *}$ \\
\hline TS-LKD & $942^{* *}$ & $876^{* *}$ & $944^{* *}$ & 1 & $956^{* *}$ & $977^{* *}$ \\
\hline LRLS & $858^{* *}$ & $842^{* *}$ & $960^{* *}$ & $956^{* *}$ & 1 & $945^{* *}$ \\
\hline LLRA-KŠS & $925^{* *}$ & $906^{* *}$ & $894^{* *}$ & $977^{* *}$ & $945^{* *}$ & 1 \\
\hline
\end{tabular}

*. Koreliacijos koeficiento reikšmingumas atitinka sąlygą $0,01<p<0,05$

**. Koreliacijos koeficiento reikšmingumas atitinka sąlygą $0,01>p$

Čia nustatyti išskirtinai stiprūs ryšiai tarp visų šešių parlamentinių politinių partijų rinkimų programų, o pats stipriausias ryšys nustatytas tarp TS-LKD ir LLRA-KŠS (koreliacijos koeficientas $r=0,977$ ). Kiti glaudūs ryšiai tarp partijų, lyginant jų programas semantinių segmentų pagrindu (vardijama mažèjančia tvarka): tarp LRLS ir TT (koreliacijos koeficientas $r=0.960$ ), tarp LRLS ir TS-LKD $(r=0.956)$, tarp LSDP ir LVŽS $(r=0.948)$, tarp LLRA-KŠS ir LRLS $(r=0,945)$, tarp TS-LKD ir TT $(r=0.944)$, tarp TS-LKD ir LVŽS $(r=0.942)$, tarp LLRA- 
Daiva Sirtautienè, Lilija Petraitienè

KŠS ir LVŽS $(r=0.925)$, tarp LLRA-KŠS ir LSDP $(r=0.906)$ ir t. t. Žvelgiant i skaičių dinamiką galima pastebèti, kad šiek tiek labiau su kitomis programomis susijusi TS-LKD programa, silpnesni ryšiai už visas likusias - LSDP programoje (čia užfiksuotas vienintelis nelabai stiprus, o tik stiprus ryšys - su TT $(r=0.739)$ ).

Ivertinus semantinių segmentų kriterijaus koreliacinès analizès rezultatus galima teigti, kad vertybių raiškos semantiniai laukai visose partijų programose labai panašūs, tad kalbėti apie ryškesnius skirtumus tarp programų netenka. Kita vertus, galima matyti visų partijų sieki komunikuoti kuo platesni valstybès valdymo ir visuomenės gyvenimo aktualijų spektrą.

\section{Ideologinių vertybiụ komunikavimo programose rezultatai}

Žinia, programose deklaruojamos vertybès (bendražmogiškosios, socialinès) turètų atskleisti partijų ideologinę tapatybę ir rodyti tam tikrą takoskyrą tarp jų. Todèl pirmiausia, remiantis mokslo šaltiniuose pateikiama tradicinių partijų ideologijų analize (Nisbet, 1993; Thorson, Sabine, 2008; Berlin, 1995; Jokubaitis, 1997; Lavišius, 2008; Nozick, 2003; Lijphart, 2014), išskirtos šioms partijoms būdingos vertybės: konservatizmo (apibendrintai akcentuojančio tradiciją, kuri tyrime skaidyta, atsižvelgiant ir ị dabarties aktualijas): šeima, bendruomenè, darna, žmogus, gyvybe்; liberalizmo: laisvė, žmogus (individas), lygybė (prieš ịstatymus), galimybès; socialdemokratijos: darbas, teisingumas, gerovė, bendruomeniškumas, lygybė, solidarumas. Kitų partijų ideologinès vertybès mokslo šaltiniuose ne tiek išplètotos, daugiau kalbama apie ideologijų jungtis - populizmą (Stanley, 2008, De Raadt ir kt., 2004), tad remtasi gretutinių dokumentų apžvalga, pvz., Europos žaliujų partijos manifestu (EGP) ar pačių partijų įstatais. Taigi išryškèjo: žaliųjų / valstiečių: solidarumas, darna, teisingumas (socialinis), lygybė (lyčių), šeima, gyvybė; liberalų demokratų (TT): gyvybè, laisvė, lygybè, teisingumas; jau LLRAKŠS pavadinime atskleistos šeima ir Lietuva (pamatinè ir kitų partijų vertybė), be to, deklaruojami teisingumas, žmogus, laisvè, gerovè.

Ideologinių vertybių raiškos programose rezultatai pateikti 6 lentelèje. Išskirtų vertybių paieškos procese dėmesys kreiptas ir ị kontekstą, pvz., žodžių junginyje laisvés atèmimas esanti vertybè nepriskaičiuota. Su tokiais atvejais susidurta, nes paieška vykdyta visame programų tekste.

Kokios ideologinès vertybès ir kurių partijų programose atskleidžiamos ryškiausiai - permanentiškai per visą programą? Tai parodo santykis tarp vertybès raiškos partijos programoje ir vidurkio. Labiausiai išsiskiria LVŽS partija, deklaruojanti darna (net 3,6 karto dažniau už vidurkị). Labai išsiskiriančios vertybès: LSDP - lygybe ir solidarumas (būdingos kairiesiems); LLRA-KŠS - jaunimas, šeima ir teisingumas. TT partijos ryškesnè skirtis iš kitų yra vaikai (tai būtų galima 
sieti su švietimo prioritetu šios partijos programoje) ir pagalba. LRLS programoje akcentuojamas pilietiškumas. Šias išvardytas ideologines vertybes galima laikyti išskirtiniu konkrečios partijos programos bruožu.

Mažiau besiskiriantis nuo bendrojo vidurkio yra laisvès (TT), gyvybès (LVŽS), bendruomenes (LVŽS), pagarbos (LSDP) deklaravimas paskirų partijų programose. Natūralu, kad Lietuva (laikytina ir tèvynès sinonimu) ryškiai atskleista visose Lietuvos partijų programose, bet daugiausia (beveik pusantro karto dažniau nei vidurkis) - TS-LKD, kurios jau pačiame pavadinime ịvardyta tévyne. Tas pats pasakytina ir apie darbo vertybės panašią sklaidą visose programose, bet LSDP, kaip ir priklausytų, ją aktualizuoja labiausiai, nors nuo statistinio vidurkio labai nenutolta. Beje, LVŽS programoje darbui skiriama mažiausia dèmesio, palyginus su likusiomis programomis.

Taigi santykinių procentinių dažnių rezultatai (didesni ar mažesni) lyg ir rodytų atitikimo tendenciją, bent jau tradicinių partijų ideologijų principams, nors yra ir tam tikro keistumo. Pavyzdžiui, pilietiškumas TS-LKD programoje aptinkamas perpus rečiau nei vidutiniškai, nors Tèvynė be piliečių nelabai ịsivaizduojama.

Be to, žvelgiant ị visus santykinius dažnius, galima pastebèti ir labai panašų tam tikros vertybès atskleidimą skirtingų ideologijų programose, pvz., plg. darba (TT ir TS-LKD bei LRLS ir LLRA-KŠS), parama (LSDP, TT, TS-LKD, LRLS), gerove (LVŽS, LSDP, TS-LKD). Tokių panašumų, issigilinus, yra ir daugiau (žr. 6 lentelę).

Lyginant procentinès analizès rezultatus galima matyti tris ideologinių vertybiu atskleidimo ypatybes: labai ryškus vertybès dominavimas programos tekste; išsiskiriantis vertybès deklaravimas, bet netolimas bendram visų programų vidurkiui; panaši tarpprograminè vertybès raiška. Dažnesnè yra pastaroji tendencija, ką atskleidžia ir koreliacinès analizès rezultatai (žr. 7 lentelę).

6 lentele. Ideologinių vertybių komunikacija partijų programose (santykiniai dažniai, procentais)

\begin{tabular}{|l|l|l|l|l|l|l|l|}
\hline \multirow{2}{*}{ Vertybės } & \multicolumn{9}{|l|}{ Partijos } & LVŽS & LSDP & TT & TS-LKD & LRLS & $\begin{array}{l}\text { LLRA- } \\
\text { KŠS }\end{array}$ & $\begin{array}{l}\text { Viduti- } \\
\text { niškai }\end{array}$ \\
\cline { 2 - 8 } & 19,4 & 23,5 & 20,4 & $\mathbf{3 4 , 2}$ & 29,3 & 19,2 & 24,3 \\
\hline Lietuva & 16,0 & $\mathbf{2 6 , 2}$ & 22,2 & 22,9 & 19,9 & 19,2 & 21,1 \\
\hline Darbas & 8,9 & 5,2 & $\mathbf{1 7 , 4}$ & 5,8 & 7,5 & 10,6 & 9,2 \\
\hline Vaikai & 9,4 & 4,9 & 6,0 & 4,4 & 4,7 & $\mathbf{1 3 , 7}$ & 7,2 \\
\hline Šeima & $\mathbf{9 , 1}$ & 6,2 & 5,4 & 8,6 & 8,6 & 2,0 & 6,6 \\
\hline Galimybės & $\mathbf{9}, 8$ & 2,2 & $\mathbf{6 , 9}$ & 2,1 & 4,5 & 2,7 & 3,9 \\
\hline Pagalba & 4,8 & & & & & \\
\hline
\end{tabular}


Daiva Sirtautienè, Lilija Petraitienè

\begin{tabular}{|c|c|c|c|c|c|c|c|}
\hline \multirow[b]{2}{*}{ Vertybès } & \multicolumn{7}{|c|}{ Partijos } \\
\hline & LVŽS & LSDP & TT & TS-LKD & LRLS & $\begin{array}{l}\text { LLRA- } \\
\text { KŠS }\end{array}$ & \begin{tabular}{|l} 
Viduti- \\
niškai
\end{tabular} \\
\hline Parama & 5,4 & 3,0 & 2,7 & 3,3 & 3,4 & 5,1 & 3,8 \\
\hline Bendruomenè & 5,7 & 3,1 & 2,1 & 4,3 & 4,9 & 2,4 & 3,7 \\
\hline Jaunimas & 1,3 & 4,9 & 2,1 & 2,7 & 2,0 & 8,6 & 3,6 \\
\hline Žmogus & 3,7 & 4,1 & 3,9 & 1,3 & 3,0 & 2,7 & 3,1 \\
\hline Pagarba & 3,4 & 4,3 & 1,8 & 3,0 & 2,1 & 2,4 & 2,8 \\
\hline Gerovè & 2,7 & 2,6 & 0,3 & 2,8 & 2,2 & 2,0 & 2,1 \\
\hline Teisingumas & 0,6 & 2,8 & 2,1 & 1,4 & 0,5 & 3,9 & 1,9 \\
\hline Darna & 6,2 & 0,9 & 0,3 & 0,2 & 1,5 & 1,2 & 1,7 \\
\hline Laisvè & 0,6 & 1,6 & 2,7 & 1,5 & 2,0 & 1,6 & 1,7 \\
\hline Pilietiškumas & 1,1 & 1,1 & 2,1 & 0,6 & 2,3 & 0,8 & 1,3 \\
\hline Solidarumas & 0,2 & 2,1 & 1,2 & 0,5 & 0,4 & 0,8 & 0,9 \\
\hline Gyvybè & 1,3 & 0,5 & 0,6 & 0,3 & 1,0 & 0,8 & 0,8 \\
\hline Lygybè & 0,1 & 0,9 & 0,0 & 0,3 & 0,3 & 0,4 & 0,3 \\
\hline
\end{tabular}

Koreliacinès analizès rezultatai pateikti 7 lentelëje.

7 lentele. Ryšiai tarp partijų programų: ideologinių vertybių kriterijus

\begin{tabular}{|l|l|l|l|l|l|l|}
\hline Partija & LVŽS & LSDP & TT & TS-LKD & LRLS & LLRA-KŠS \\
\hline LVŽS & 1 & $867^{* *}$ & $869^{* *}$ & $901^{* *}$ & $929^{* *}$ & $844^{* *}$ \\
\hline LSDP & $867^{* *}$ & 1 & $873^{* *}$ & $951^{* *}$ & $937^{* *}$ & $871^{* *}$ \\
\hline TT & $869^{* *}$ & $873^{* *}$ & 1 & $848^{* *}$ & $882^{* *}$ & $871^{* *}$ \\
\hline TS-LKD & $901^{* *}$ & $951^{* *}$ & $848^{* *}$ & 1 & $991^{* *}$ & $830^{* *}$ \\
\hline LRLS & $929^{* *}$ & $937^{* *}$ & $882^{* *}$ & $991^{* *}$ & 1 & $826^{* *}$ \\
\hline LRA & $844^{* *}$ & $871^{* *}$ & $871^{* *}$ & $830^{* *}$ & $826^{* *}$ & 1 \\
\hline
\end{tabular}

**. Koreliacijos koeficiento reikšmingumas atitinka sąlygą $0,01>p$

Koreliacinè analizė atskleidè, kad čia visur fiksuojamas labai stiprus ryšys tarp partijų. Traktuoti ryšio tarp LRLS ir LLRA-KŠS programų šiame tyrime kaip silpną ( $r=0,826$ - mažiausias koeficientas matricoje) negalima, nes net ir šis ryšys labai stiprus (atitinka sąlygą $r>0,8$ ). Pats stipriausias ryšys yra tarp abiejų 
dešiniosios ideologijos partijų - TS-LKD ir LRLS (koreliacijos koeficientas $r=$ 0,991), tad šių partijų programos ideologinių vertybių požiūriu laikytinos beveik identiškomis.

Galima dar palyginti, kurių partijų programos ideologinių vertybių pagrindu labiausiai susijusios, o kur dar galima atrasti kiek daugiau neatitikimų. Klasikinei kairiajai ideologijai turètų atstovauti LSDP partija, bet iš tiesų ji labiausiai susijusi su TS-LKD $(r=0,951)$ ir LRLS $(r=0,937)$, su kitomis LSDP turi daugiau neatitikimų: su LVŽS ( $r=0,867)$, LLRA-KŠS $(r=0,871)$, TT $(r=0,873)$, bet ryšys ir su šiomis partijomis visgi yra labai stiprus.

2016 m. Lietuvos Respublikos Seimo rinkimų nugalètoja LVŽS stipriausią ryši turi taip pat su dešiniosios ideologijos partijomis LRLS $(r=0,929)$ ir TS-LKD $(r=0,901)$, šiek tiek silpnesni - su TT $(r=869)$ ir LSDP $(r=867)$, sąlygiškai silpniausias ryšys - su LLRA-KŠS ( $r=844)$. Partijos LLRA-KŠS ryšys su LSDP ir TT identiškai vienodo stiprumo $(r=0,871)$.

Lyginant trijų kriterijų koreliacinès analizès rezultatus, išsiskiria apimties kriterijus, kur koreliacijos buvo mažiausios. Tiek ideologinių vertybių, tiek semantinių segmentų kriterijaus taikymo rezultatai panašūs - pasižymi ypač stipriais koreliacijos koeficientais. Vis dèlto išsiskiria stebėtinai didelè koreliacija tarp TS-LKD ir LRLS - 0,991, jų programos ideologinių vertybių pagrindu beveik tapačios.

\section{Partijụ programų tarpusavio sąsajos - hierarchinių klasterių analizė}

Kadangi koreliacinès analizès metodas atskleidžia tarpusavio ryšius ir jų intensyvumą tik tarp paskirų imties porų, siekta nustatyti ir visų šešių programų tarpusavio sąsajas. Tam taikytas hierarchinių klasterių metodas, skirtas imties vienetams grupuoti pagal jų panašumą, kai jungtys atliekamos žingsnių principu: kuo mažiau žingsnių iki jungties, tuo didesnis panašumas ir atvirkščiai.

Atlikus kiekvieno kriterijaus duomenų klasterizaciją išryškèjo, kad semantinių segmentų kriterijus savo rezultatais šiek tiek skiriasi nuo kitų dviejų. Kaip matyti dendrogramoje (žr. 1 pav.), atsižvelgiant ị tirtujų reikšmių sklaidą visoje programoje, pirmoji ir tik vieno žingsnio jungtis yra tarp TS-LKD ir LLRA-KŠS partijų (kaip ir galima buvo tikètis, atsižvelgiant ị stipriausią ryši segmentų matricoje, žr. 5 lentelę). Tad iš šitų partijų susidaro pirmasis klasteris. Dar po dviejų žingsnių prie jo prijungiama LRLS; be to (trijų žingsnių principu), LVŽS sujungiama su LSDP (antrasis klasteris). Po 11-os žingsnių šie abu klasteriai sujungiami ì vieną bendrą. Žvelgiant jau iš laiko perspektyvos galima tik pastebėti, kad ši LVŽS ir LSDP jungtis atskleidžia realiai po rinkimų sudarytą koaliciją. TT partijai būdinga akivaizdi atskirtis. 


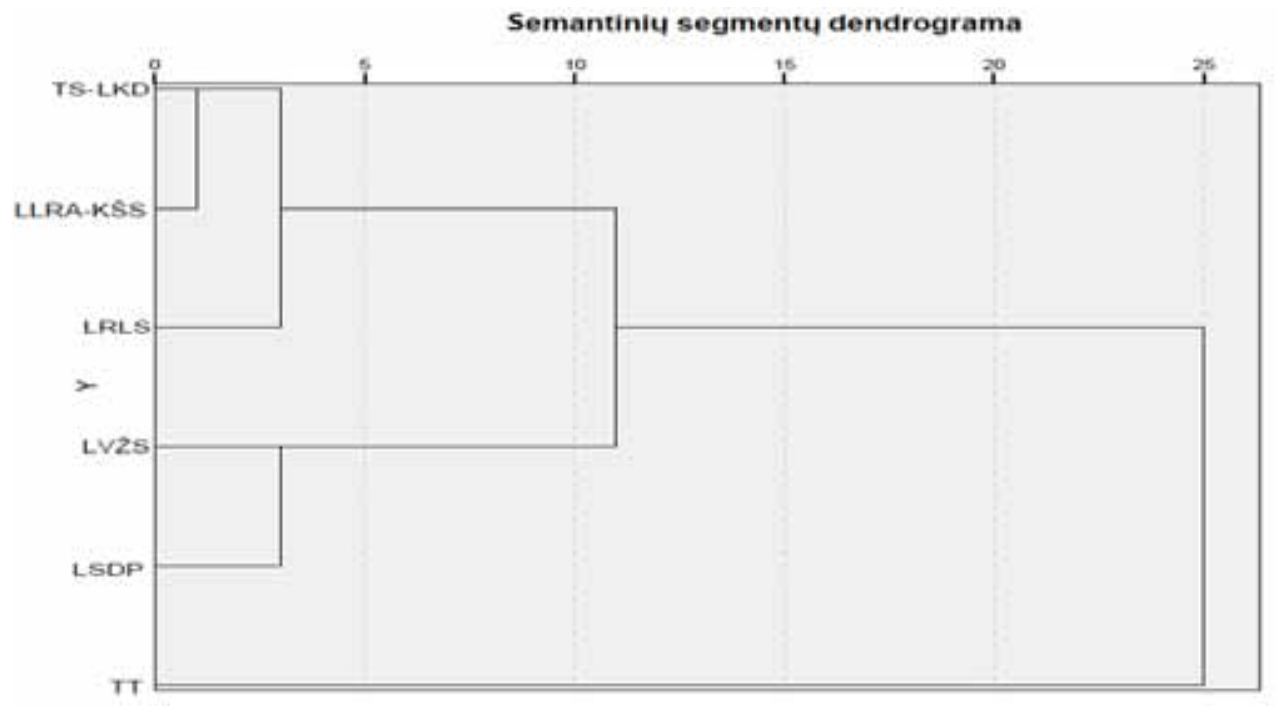

1 pav. Partijų programų tarpusavio sąsajos pagal semantinių segmentų kriterijų

LVŽS su LSDP savo priešrinkiminėse programose turëjo pagrindą po laimètu rinkimų susijungti. Tai buvo ne ideologinis pagrindas, o dabarties aktualijų bendras supratimas (šiame tyrime semantiniai segmentai skaičiuoti laisvai pasirenkant pagal aktualijas): šių aktualijų deklaravimu programose abi partijos buvo artimiausios.

Kitokios (nei segmentų pagrindu) sąsajos tarp programų nustatytos, pasitelkus struktūrinių dalių apimties ir ideologinių vertybių duomenis. Iškart atkreiptinas dèmesys ị rezultatą: šie skirtingi kriterijai atskleidžia tokị pat partijų programų grupavimo eiliškumą, tik kai kur skiriasi jungties žingsnių skaičius (žr. 2 ir 3 pav.). Manytina, kad, viena vertus, semantinių segmentų analizės metodas ateityje tikslintinas, labiau detalizuojant bei išplečiant reikšmių lauką, kita vertus, akivaizdus yra ideologinių vertybių ir teminių dalių apimties, kaip pasirinktų tyrimo kriterijų, mokslinis pagrịstumas. Tai atskleidžia ir laiko tėkmèje vykstantys procesai Lietuvos Seime (tekstinę iliustraciją žr. žemiau).

Kaip matyti abiejose dendrogramose, artimiausios yra tradicinių partijų jungtys: natūrali dešiniuju - TS-LKD ir LRLS ir kiek savotiškai prie jų atrodanti kairiujų LSDP (kiek greičiau ị jų klasterị prijungiama struktūrinių dalių pagrindu). Abiem atvejais LVŽS (dešimtas ir penkioliktas žingsniai) sujungiama ị bendrą klasterị su LLRA-KŠS, o TT partija, išliekanti didžiausioje atskirtyje nuo kitų struktūrinių dalių apimties pagrindu, vis dèlto priartejja prie LVŽS ir LLR-KŠS ideologinių vertybių lygmeniu, nors tik septynioliktu žingsniu (plg. visas tris dendrogramas). 


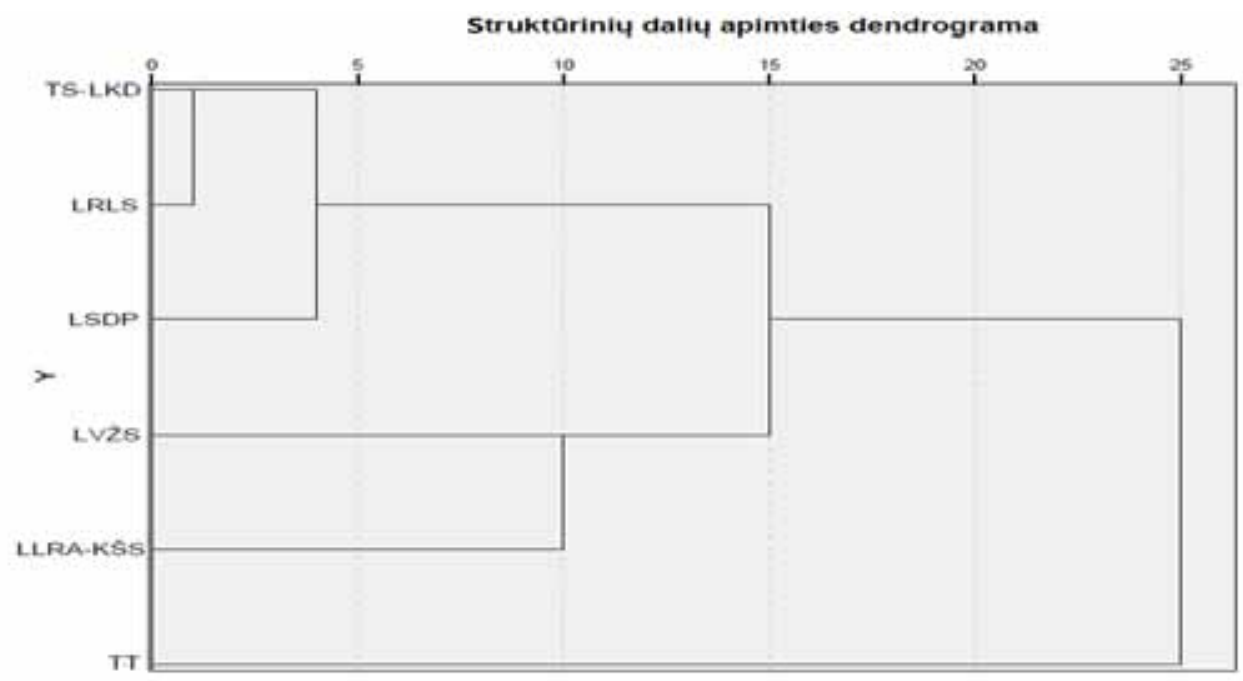

2 pav. Partijų programų tarpusavio sąsajos pagal teminių dalių apimties kriterijų

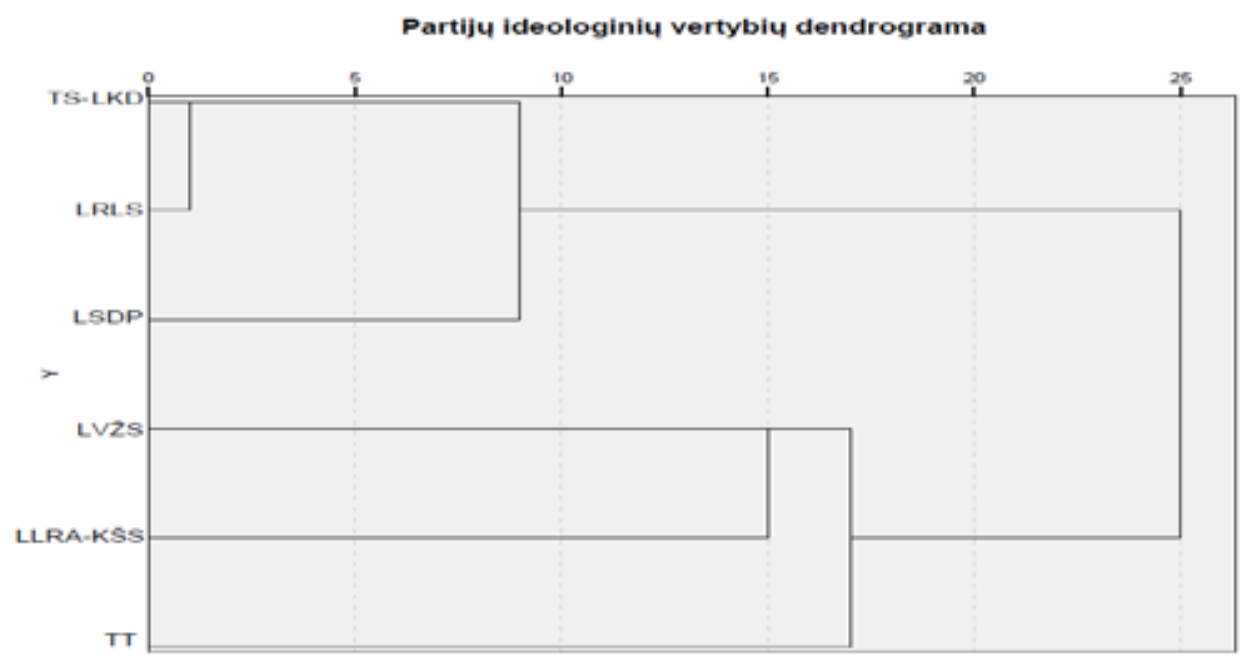

3 pav. Partijų programų tarpusavio sąsajos pagal ideologinių vertybių kriterijų

İdomu pastebėti, kad taip politologų mėgstamas O. Kernberg’o (2016) modelis apie bendras ir kuo labiau sutampančias visuomenès bei politinès sistemos vertybes, kurių pagrindu formuojasi patvaresnè visuomenè, realiai atskleidžiamas ne tik vadinamujų populistiniu (lot. populus - liaudis, TŽŽ, 2003, p. 591) partijų, ku- 


\section{Daiva Sirtautienė, Lilija Petraitienè}

rioms paprastai suteikiamas neigiamos konotacijos kontekstas, bet ir vadinamuju tradiciniu partijų, tai įrodo iš LSDP ir TS-LKD bei LRLS susidaręs bendras klasteris. Kitaip tariant, kairiosios ir dešiniosios partijos sujungtos į bendrą klasterị todèl, kad ir jos siekè apimti kuo platesnị visuomenès vertybinių nuostatų lauką. Be to, tarp šių trijų tradicinių partijų programų nustatyti mažiausi ideologiniai skirtumai, kitų partijų programos labiau išsiskiria, tiesa, LVŽS ir LLRA-KŠS programos šiek tiek panašios viena ị kitą, o TT programa, nors yra pati originaliausia, ideologinių vertybių pagrindu vis dèlto labiau sietina su pastarosiomis.

2016 m. partijų programų medžiagos tyrimo rezultatai laikui bėgant ịgvendinami, pvz., LVŽS kontaktų su LLRA-KŠS ir TT paieška: kaip interviu S. Jakučioniui teigė R. Karbauskis, ,jiems (LLRA-KŠS - aut.) niekada nereikèjo susitarimų, kad jie vertybiniu požiūriu balsuotų kartu su mumis“; „,Valstiečiai““ ir „,tvarkiečiai““ šiuo metu svarsto sudaryti frakcijų bendradarbiavimo sutartị, derybos turètų baigtis rugpjūtị““ (Jakučionis, 2018). Kaip jau žinoma, koalicinè sutartis tarp LVŽS ir TT jau sudaryta, prie jos prisijungè ir LSDDP (Socialdemokratų darbo partija), atsiradusi po LSDP skilimo), o LLRA-KŠS partija dalyvauti koalicijoje atsisakè.

\section{Išvados}

Kaip rodo mokslininkų, analizuojančių rinkimų ị LR Seimą dinamiką, tyrimai, kartais pasitaiko prognozių dèl rinkimų baigties, kurios neatitinka rezultatų. Tą parodè ir pastarieji 2016 m. rinkimai. Iprastesni yra rinkèjų arba politikų, kaip paskirų dimensijų, tyrimai. Daugiau dèmesio būtų verta skirti priešrinkiminių partijų programų analizei, kaip instrumentui, galinčiam pirmiausia išryškinti partijų skirties ir sąlyčio taškus, atskleidžiančius realias, o ne išankstines bendradarbiavimo (koalicijų sudarymo) nuostatas LR Seime.

Nustatyti šie vertybiniai prioritetai partijų programose: LVŽS - sveikata, socialinè apsauga, aplinkosauga, teisingumas, darna; LSDP - saugumas, teisingumas, lygybè, solidarumas; TT - švietimas, vaikai, pagarba; TS-LKD - ūkio augimas, Lietuva; LLRA-KŠS - kultūra, savivalda, šeima, jaunimas, teisingumas; LRLS pilietiškumas (ir tai yra vienintelè nustatyta prioritetinė sritis, išskirianti šią partiją iš kitų).

Koreliacinès analizès rezultatai atskleidè, kad pagal temines programų dalių apimtis labiausiai tarpusavyje panašios yra trys tradicinėmis vadinamų partijų programos: TS-LKD, LRLS ir LSDP, o labiausiai tarpusavyje besiskiriančios - LVŽS

ir LLRA-KŠS programos. Savo dalių apimties struktūra išskirtiniausia yra LVŽS programa, nes labiausiai nesuderinama su kitomis: visi neigiami ryšiai užfiksuoti tik tarp jos ir likusių programų, tiesa, tik vienas iš jų - su LLRA-KS̆S - statistiškai reikšmingas. 
Atlikus partijų programų koreliacinę analizę pagal semantinių segmentų sklaidą jose, nustatyti išskirtinai stiprūs ryšiai tarp visų programų, tad galima teigti, kad aktualizuojamų reikšmių prasme rinkimų programos yra labai panašios. Tai būtų galima paaiškinti partijų siekiamybe komunikuoti visuomenei svarbias problemas / temas (aktualijas), orientuojantis ị daugumos rinkèjų lūkesčius, kurie, tikètina, yra panašūs. Kita vertus, tai atskleidžia, kad nè viena partija neturi (ar nelabai gali turèti) reikšmingos išskirtinès linijos, kuri galimai ir nesulauktų plataus atgarsio visuomenèje.

Labai panašų rezultatą atskleidè ir ideologinių vertybių koreliacinė analizė, tad galima dar kartą konstatuoti, kad partijų rinkimų programos ir ideologinių vertybių prasme yra labai panašios, ideologinė takoskyra yra silpna.

Atlikus hierarchinių klasterių analizę visų trijų kriterijų atvejais, nustatyta, kad pirmajame klasteryje stabili yra TS-LKD ir LLRS jungtis (tai atskleidè ir kitų metodų taikymo rezultatai), labiausiai nutolusi nuo kitų yra TT partijos programa.

Dviejų kriterijų - ideologinių vertybių ir teminių programų dalių apimties hierarchinių klasterių dendrogramos beveik identiškos, tai atskleidžia šių kriterijų taikymo patikimumą. Jais remiantis, nustatyta, kad LR Seimo parlamentinių partijų, $2016 \mathrm{~m}$. laimèjusių rinkimus, programoms būdingi šie klasteriai: pirmajị sudaro TS-LKD ir LLRS, kiek vèliau prijungiant LSDP, antraji - LVŽS ir LLRAKŠS, ideologinių vertybių raiškos pagrindu prie pastarujų šiek tiek priartèjusi TT partija. Taigi dabartiniame LR Seime, remiantis vertybinių prioritetų komunikacija programose, yra du partijų blokai, j̨vardytini kaip: a) tradicinių ir b) kitų.

Turint omenyje tai, kad LR partijų programose, kuriose beveik vienodai aktualizuojamos pirmiausia socialinès (o ne ideologinès) vertybės, reikètų atkreipti dėmesi ị asmenybių reikšmę rinkimuose, kurios jaučia rinkèjų lūkesčius ir geba tinkamai komunikuoti visuomenei svarbias vertybes.

\section{Literatūra}

Baudrillard, J. (2002). Simuliakrai ir simuliacija. Vilnius: Baltos lankos. ISBN 9955-00-011-2.

Bendorienè, A. ir kt. (2003). Tarptautinių žodžių žodynas. Vilnius: Alma littera. ISBN 9955-08-100-7.

Berlin, I. (1995). Vienove ir ịvairové: žvilgsniai ị ideju istoriją. Vilnius: Amžius. ISBN 9986-430-21-6.

Bielinis, L. (2005). Visuomenè, valdžia ir žiniasklaida. Prieštaringa komunikacinè simbiozé. Vilnius: Eugrimas. ISBN 9955-682-10-8.

Čekanavičius, V., Murauskas, G. (2004). Statistika ir jos taikymas II. Vilnius: TEV. UDK 311(075.8).

De Raadt, J., Hollanders, D., Krouwel, A. (2004). Varieties of Populism: An Analysis of the Programmatic Character of Six European Parties. Amsterdam: Working Papers Political Science Vrije Universiteit. ISBN (Electronic) 1569-3546.

Europos žaliujų partijos (EGP) manifestas. Prieiga internete: https://europeangreens.eu/manifesto/lithuania.

Habermas, J. (1983). Moralbewußtsein und kommunikatives Handeln. Frankfurt am Main: Suhrkamp. ISBN 978-3-518-28022-5.

Jakučionis, S. (2018). Karbauskis: LLRA-KS̆Sgaligauti Seimo vicepirmininkoposta. Prieiga internete: https://www. delfi.lt/news/daily/lithuania/karbauskis-llra-kss-gali-gauti-seimo-vicepirmininko-posta.d?id=78770797. 


\section{Daiva Sirtautiené, Lilija Petraitienè}

Jastramskis, M. (2013). Lietuvos politinių partijų vertybių žemèlapis. Vilnius: Žmogaus teisių stebẻjimo institutas. ISBN 978-609-437-158-5.

Jastramskis, M. (2017). 2016 metų Seimo rinkimų iššūkis partinei sistemai ir politologams: kaip numatyti žemės drebejjimą? Politologija, Nr. 2, p. 3-43.

Jokubaitis, A. (1997). Postmodernizmas ir konservatizmas. Kaunas: Naujasis lankas. ISBN 9986-550-85-8.

Jovaiša, L. (2009). Auklèjimas priedermès masteliu. Acta Paedagogica Vilnensia, T. 22, p. 52-64.

Kernberg, O. (2016). La personnalite narcissique. Paris: Dunod. ISBN 978-2-10-074580-7.

Lavišius, T. (2008). Politiniu ideologiju istorija ir šiuolaikinè demokratija. Ka turime bendro? Prieiga internete: http://www.xxiamzius.lt/numeriai/2008/11/26/istdab_03.html.

Lijphart, A. (2014). Patterns of Democracy: Government Forms and Performance in Thirty-Six Countries. Michigan: Cumberland Yale University Press. ISBN 9780300189124.

LLRA-KŠS Seimo rinkimu programa. Prieiga internete: http://www.awpl.1t/?p=4768\&lang=1t.

LRLS Seimo rinkimu programa. Prieiga per internetą: https://www.liberalai.lt/rinkimai/rinkimu-programa.

LSDP Seimo rinkimu programa. Prieiga internete: http://www.lsdpklaipeda.lt/lietuvos-socialdemokratu-partijos2016-m-seimo-rinkimu-programa/.

LVŽS Seimo rinkimu programa. Prieiga per internete: http://darnilietuva.lt/.

Nietzsche, F. (1991). Rinktiniai raštai. Vilnius: Mintis. ISBN 5417029068.

Nisbet, R. (1993). Konservatizmas. Vilnius: Pradai.

Norkus, Z. (1995). Aleksijaus Mainongo ,asmeninès vertès“ teorija tarp aksiologinių diskursų. Problemos, T. 48, p. $14-29$.

Novagrockienè, J. (1995). Partinès sistemos ir jų tipologija. Politologija, Nr. 1, p. 54-72.

Nozick, R. (2003). Anarchija, valstybè ir utopija. Vilnius: Eugrimas. ISBN 9789955501503.

Popper, K. R. (1998). Atviroji visuomene ir jos priešai. Vilnius: Pradai. ISBN 9986776791.

Pruskus, V. (2005). Vertybès rinkoje: squveika ir pasirinkimas. Vilnius: Vilniaus pedagoginis universitetas. ISBN 9955-20-002-2.

Ramonaite, A. (2009). Partinès demokratijos pabaiga? Politinis atstovavimas ir ideologijos. Vilnius: Versus aureus. ISBN 978-9955-34-262-5.

Ramonaitè, A. (2007). Posovietinès Lietuvos politiné anatomija. Vilnius: Versus aureus. ISBN 978-9955-69984-2.

Ramonaitė, A., Jastramskis, M. ir kt. (2014). Kaip renkasi Lietuvos rinkëjai? Idejos, interesai ir ịvaizdžiai politikoje. Vilnius: Vilniaus universiteto leidykla. ISBN 978-609-459-370-3.

Scheler, M. (2012). Der Formalismus in der Ethik und die materiale Wertethik. London: Sarastro. ISBN 9783864711602.

Sirtautas, V., Sirtautienė, D. (2013). Visuomenès vertybių prioritetų raiška Lietuvos respublikiniuose dienraščiuose. Tiltai, Nr. 3, p. 83-101.

Stanley, B. (2008). The Thin Ideology of Populism. Journal of Political Ideologies, Vol. 13, Nr. 1, p. $95-110$.

Thorson,T. L., Sabine, G. H. (2008). Politiniu teoriju istorija. Vilnius: Margi raštai. ISBN 978998609349.

TS-LKD Seimo rinkimu programa. Prieiga internete: https:/tsajunga.lt/wp-content/uploads/2017/10/TS-LKDnaujas-planas-Lietuvai.pdf.

TT Seimo rinkimu programa. Prieiga internete: http://tvarka.lt/lt/apie-mus/seimo-rinkimu-programa-2016.

Žiliukaitè, R. ir kt. (2006). Neatrasta galia. Lietuvos pilietinès visuomenès žemélapis. Vilnius: Versus aureus. ISBN 9955-699-44-2. 
VERTYBIŲ KOMUNIKACIJOS YPATYBĖS LIETUVOS POLITINIŲ PARLAMENTINIŲ...

\title{
QUALITIES OF VALUE-BASED COMMUNICATION WITHIN THE PROGRAMS OF THE LITHUANIAN PARLIAMENT'S POLITICAL PARTIES (2016 ELECTION CASE STUDY)
}

\section{Daiva Sirtautienė, Lilija Petraitienè}

\author{
Summary
}

The object of study presented within this article - the qualities of value-based communication from the programs of political parties which successfully won the 2016 Republic of Lithuania Seimas election.

The following tasks were addressed within this paper: having analyzed the programs, to create a summary containing a structure that was common throughout all of them; to evaluate the expression of party ideological identity within their programs; to reveal the connections and differences between the declared values of the programs.

As research of the dynamics of elections to the Seimas of the Republic of Lithuania shows, studies are sometimes faced with outcomes that do not correspond to the actual results of the elections. This was recently seen within the 2016 election. It is more common to investigate voters or politicians as individual dimensions. It would be better suited to pay more attention to the analysis of pre-election party programs as an instrument capable of highlighting, in particular, the parties' divisions and contact points that reveal real, rather than prejudicial, provisions for co-operation (coalition formation) in the Republic of Lithuania Seimas.

The following value priorities have been identified in the party programs: Lithuanian Farmers and Greens Union (LVŽS) - healthcare, social security, environmental protection, justice and order; Social Democratic Party of Lithuania (LSDP) - security, justice, equality and solidarity; Order and Justice (TT) - education, children and respect; Homeland Union (TS-LKD) - economic growth and the country itself; Electoral Action of Poles in Lithuania - Christian Families Alliance (LLRA-KŠS) - culture, self-governance, family, youth and justice; Liberal Movement (LRLS) - citizenship (which is the only identified priority area that distinguishes this party from the others).

The results of the correlational analysis revealed that there are three similar socalled traditional programs according to their thematic scope: TS-LKD, LRLS and LSDP, while the most diverse programs were LVŽS and LLRA-KŠS. The LVŽS program is by far the most dissimilar due to the structure and volume of its parts, making it the most incompatible with other programs: all the negative links are 


\section{Daiva Sirtautienè, Lilija Petraitienè}

captured only between it and the rest of the programs, but only with one of them LLRA-K $\breve{S S}$ - is it statistically significant.

The correlation analysis of ideological values revealed a notably similar result, so it can be inferred once again that the election programs of the parties are very similar in terms of ideological values, having a weak ideological divide.

Having done the hierarchical cluster analysis for all three criteria, the TS-LKD and LLRS connections were noted as stable in the first cluster (which was shown by the results of other methods), while the TT party program was the most distant from the rest.

Two criteria - the scope of ideological values and the part of thematic programs - hierarchies of dendrogramic clusters were almost identical, which shows the reliability of applying these criteria. Based on this information, it was deduced that, program-specific clusters within the 2016 election winning Parliament parties of the Seimas of the Republic of Lithuania, were as follows: the first consists of the TS-LKD and LLRS, later incorporating the LSDP, and the second one - the LVŽS and LLRA-KŠS. Based on the expression of ideological values, TT latter resembled the former tow parties. Thus, two party blocks have been identifiedin the current Seimas of the Republic of Lithuania, in accordance to program priorities of value-based communication: a) traditional and b) others.

Bearing in mind that, in party programs of the Republic of Lithuania, where social (rather than ideological) values are almost equally actualized, attention should be paid to the importance of election personalities, who have a sense for voter expectations and are capable of effectively communicating values that are important to society.

Daiva Sirtautienė - docenté, daktare (socialiniai mokslai - edukologija - 07S), Klaipėdos universiteto Socialinių ir humanitarinių mokslų fakulteto Filosofijos, menotyros ir komunikacijos katedra.

Moksliniai interesai: komunikacija, žiniasklaida, edukologija.

Adresas: S. Nëries g. 5, LT-92227 Klaipèda, Lietuva.

Tel. +37060109939.

El.paštas: vytasir@gmail.com

Daiva Sirtautienè - associate professor, doctor of Social Sciences (Education - 07S), Klaipeda University, Social and Humanitarian Science Faculty, Department of Philosophy, Art Studies and Communication.

Scientific interests: communication, mass media, educology.

Address: S. Nėries Str. 5, LT-92227 Klaipėda, Lithuania.

Phone: +37060109939.

E-mail:vytasir@gmail.com 
Lilija Petraitienė - lektorè, magistrè (socialiniai mokslai - komunikacija), Klaipėdos valstybinès kolegijos, Technologijų fakultetas.

Moksliniai interesai: politinė komunikacija, derybų menas.

Adresas: Bijūnų g. 10, LT-91223 Klaipeda, Lietuva.

Tel. +370 46314928 .

El.paštas: 1ilija.petraitiene@gmail.com

Lilija Petraitienė - lecturer, master of Social Sciences (Communication) at Klaipèda State College, Faculty of Technology.

Scientific interests: political communication, art of negotiation.

Address: Bijūnų Str. 10, LT-91223 Klaipèda, Lithuania.

Phone: +37046314928 .

E-mail: lilija.petraitiene@gmail.com 